\title{
Designing Library Instruction for Students with Learning Disabilities
}

\begin{abstract}
East Carolina University is the home of an innovative program for students with learning disabilities, Project STEPP (Supporting Transition and Education through Planning Partnerships). Librarians at ECU's Joyner Library have collaborated with Project STEPP since 2010 to provide library instruction for the program's students. The researchers have considered principles of Universal Design for Learning and the special needs of students with learning disabilities in library instruction. This paper will discuss the librarians' collaboration with the STEPP program, classroom experiences and assessment with the students, and future plans for improving instruction.
\end{abstract}

$\mathrm{P}$ roject STEPP (Supporting Transition and Education through Planning Partnerships) is an innovative program for college students with learning disabilities started at East Carolina University. The program is part of Project STAR (Supporting Transition, Access, and Retention) which is a growing program that currently has representation at two other North Carolina campuses. All the programs are aimed at helping students with learning disabilities or concerned with training faculty to design more inclusive courses.

In the decade between 2000 and 2010, the number of students with diagnosed dyslexia, ADD, and ADHD more than doubled. ${ }^{1}$ With the growing number of students with identified learning disabilities studying at the university level, academic libraries are becoming more sensitive to the information needs of this population. Responding to the learning needs and styles of students with learning disabilities will require that libraries consider multiple methods of reference and instruction delivery. Considering that there are students with learning disabilities that are undiagnosed or not disclosed by the student, it is reasonable to expect that the additional methods will benefit a larger group of students than solely those registered with the campus student disabilities services. Further, what librarians learn from the methods used for teaching students with learning disabilities will help better serve all patrons by improving library instruction and reference communications.

Located in Greenville, North Carolina, East Carolina University is a public, coeducational doctoral/ research institution. Project STEPP is a collaborative program that partners with colleges and departments on campus and other area educational institutions. The librarians collaborated with two cohorts over the course of two years, 2011 and 2012. The program enrolls ten carefully selected freshmen with documented learning disabilities each year and offers academic, social, and life skills support. The students take a reduced course load and are scheduled to graduate in five years. Freshmen spend twenty hours per week in the STEPP offices for studying and tutoring. As they progress, they have fewer required study hours. The students take a series of five independent study electives. Three are taken early in the college experience and focus on time management, organization, study skills/strategies, and learning campus resources. The last two come close to graduation and are designed to help the students' transition from college to the workforce.

Universal Design for Instruction calls for goals, materials, methods, and assessment that are appropriate for the maximum number of learners. $^{2}$ In this study, the authors used repetition, slower pace, multimedia presentations (videos and online tutorials), active learning, and individual follow-ups.

\section{Literature Review}

The impact of students with learning disabilities on academic libraries has not yet received much scholarly attention. Most of the library literature concerning learning disabilities is aimed at public libraries and school media centers. For academic libraries, Nancy Black has discussed the importance of considering invisible disabilities in the delivery of services to online students. ${ }^{3}$ Mates and Booth gave a powerful reminder of the importance of serving all academic library patrons, regardless of disability. ${ }^{4}$

The idea of universal design was originally proposed by Ronald Mace, an architect. 5 Mace's focus was on barrier-free buildings that were usable to all, including those with 
physical disabilities. The idea was adapted to serve the needs of diverse students in higher education by Silver, Bourke and Stehorn in $1998 .{ }^{6}$ The concept was further refined by Zeff who proposed that Universal Design for Learning should include multiple means of representation, multiple means of expression, and multiple means of engagement. ${ }^{7}$ Universal Design for Learning with a focus on learning disabilities has been discussed by Beacham and Alty ${ }^{8}$ and Getzel, McManus, and Briel .?

Much of the library literature on serving patrons with learning disabilities has come largely from the perspective of public libraries, where the research has focused mostly on physical adaptations and reference assistance. ${ }^{10}$ Weingand gives a good overview of learning disabilities and the response of a public library in New York. ${ }^{11}$ For academic libraries, research has focused on serving students with learning disabilities but the universal design component has not been prominent. Black discussed the delivery of library services to students with learning disabilities. ${ }^{12}$ O'Connor, Chodock, and Dolinger offered ideas of applying universal design to academic library services. ${ }^{13}$ The paucity of literature suggests that the application of universal design principles to academic library services for students with learning disabilities is an area that requires further research.

\section{Research Methods}

In the fall of 2010 the Outreach Librarian, Head of Reference, and the Project STEPP Director met to begin planning the library's instruction plans for the STEPP students. The Project STEPP Director gave the librarians an overview of the program and research needs of students with learning disabilities. Proposals for collaboration and the scope of librarian involvement were discussed and the planning began. The authors used hands-on activity, peer teaching, repetition, pacing, multimedia instructional tools, and individual follow-ups.

Early in fall semester 2011, the students of Cohort 2011 attended three dedicated library instruction sessions. In their first session, they had a tour and introduction to general library services. Using the catalog and locating books on the shelf were subjects of the second session. Finally, they were introduced to article databases, scholarly publications, and evaluating websites. Later in the semester, the students also attended the instruction session routinely provided in their first and second semester freshman composition courses. They were also offered individual research consultations near the end of the semester when their papers were due. The library instruction mirrored that of ENGL 1100 (First Year English Composition). The assessment indicated that slowing the pace and repetition were helpful.

The assessment of student learning consisted of pre- and post-tests. The pre-test was given at the beginning of their first instruction session and the students took the post-test online after their first major English paper near the end of fall semester or beginning of spring semester. The authors now have two years of test and survey data for the STEPP students. Using a variety of assessment tools, teaching methods for incoming Project STEPP cohorts have been adapted and these methods may be applied to general freshmen English students. Thus far, the authors have administered a preand post-test designed for STEPP cohorts and a citation analysis of Cohort 2011's papers.
The pre- and post-test included five questions about student confidence levels in using library resources and five questions about conducting research. (See Appendix) At the time they took the pre-test, the students had no formal library instruction sessions with us. After the pretest, they received three instruction sessions and at least one instruction session with their freshman English composition class. The authors compared the pre- and post-test results to assess the library skills gained by the students during these sessions. The authors have also done a citation analysis of Cohort 2011's second semester English composition papers. (Fig. 1)

As a result of post-tests with Cohort 2011, the authors followed the same basic instruction program but added greater emphasis on reading citations, understanding call numbers, and locating books in the stacks for Cohort 2012. For example, more time was spent discussing the correct MLA format and where they can locate bibliographic information from websites, books, and electronic journal articles. In typical ENGL 1100 classes, students learn Library of Congress Classification by shelving books on a virtual book truck. This same activity was not as successful with Cohort 2011 as it took a lot of class time to complete the activity. After consulting with the STEPP staff, placing physical books in order proved to be more successful. Another unique activity included looking up the call numbers for book titles and physically pulling them from the shelves.

\section{Results}

In general, Cohort 2011 and Cohort 2012 gained more confidence in conducting library research as their freshman year progressed. However, 


\section{Citation Analysis of Cohort 2011}

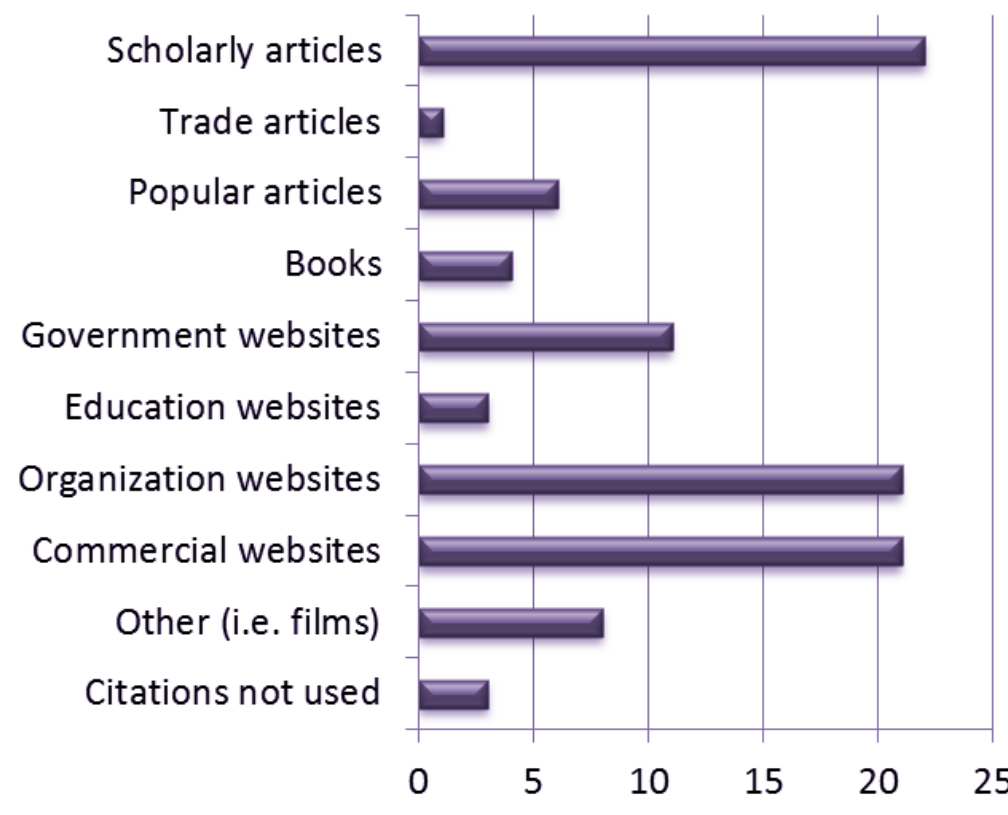

Percentage of Citations

Cohort 2012 indicated a more positive response towards library research in the post-test results than Cohort 2011. Cohort 2011 either maintained or decreased their confidence level in finding books in the library. Cohort 2012 greatly increased their confidence level in locating books between the pre- and post-test. In the post-test, $100 \%$ of students in Cohort 2012 were Somewhat or Very Confident in locating books, attributing these results from the more interactive call number activities.

Seventy-five percent of Cohort 2011 were confident in locating articles on the pre-and post-test while Cohort 2012 were less confident with 28\% Not Very Confident, 43\% Somewhat, and 29\% Not Confident on the pre-test. However, $75 \%$ of Cohort 2012 were very confident in the post-test. Both Cohorts showed improvement with avoiding plagiarism with $75 \%$ being Very Confident and 25\% being Somewhat Confident in the post-test.
In reviewing the quantitative data, Cohort 2011 was more successful overall in using criteria to evaluate websites. Cohort 2011 correctly identified a webpage's layout/design, author's credentials, and date as key criteria in evaluating a website, whereas Cohort 2012 identified discovering the site through a popular/ trusted search engine as a sufficient criterion for evaluating websites. One explanation for Cohort 2012's response may be that Joyner Library began using Summon, a library discovery tool that searches physical materials and various databases in spring 2012. Since Summon works like Google for library research, it may be interpreted as a search engine. Based on the student posttests, the authors plan to incorporate a separate website evaluation learning activity in the future. The authors asked the students to identify the summary of an article in the pre- and post-test. All of Cohorts 2011 and 2012 answered that the abstract was a summary of an article.
Since Library of Congress classification often presents a challenge to students, the authors included a question about it on the test. Fifty percent of students in Cohort 2011 answered that 'books are arranged by topic' as the correct answer in the pre-test, but many answered incorrectly on the post-test. The authors reworked this portion of the instruction for Cohort 2012. As the numbers did not improve with Cohort 2012, this is still an area that needs to receive more focus in instruction sessions. This trend is also reflected in general English composition courses. Typically, the librarians instruct students to get three pieces of information to find a book: title, call number, and location. This may influence some of the students' answers on the post-test and revision of the test question or instruction may be needed.

The last question asks students to identify the type of material (journal article, book, website, book article) given only the citation of a journal 
article. The majority of both Cohorts 2011 and 2012 correctly identify the citation as an article in the pre-test. However, some of the students in both cohorts answered the question incorrectly on the post-test. Again, using the assessment data from Cohort 2011, the authors focused more on citations with Cohort 2012. The problem may be that the test shows the citation in APA format and the students are more familiar with MLA, which they use in the freshmen English courses and in high school. The authors plan to change the format in the future and include an additional citation activity during the Project STEPP library program.

In addition to the pre- and post-tests, the authors conducted a citation analysis of Cohort 2011's final paper in their second semester English composition course. For the assignment, the students had to research an issue in their future career which allowed students to use a variety of sources. Overall, 22\% of citations were from scholarly articles. Additionally, $21 \%$ of papers had organization and commercial website citations. Both scholarly sources and professional organization websites were emphasized in their English class library instruction sessions.

\section{Conclusions}

The authors' experience indicates that repetition and slower pacing are useful tools for library instruction for students with learning disabilities. Reflecting the literature on universal design, the authors also emphasized group activities and multimedia presentation of concepts. The librarians used videos on plagiarism and scholarly publications to reinforce ideas. The authors greatly benefited from close contact with the Project STEPP staff who provided invaluable advice regarding teaching methods, such as repetition and slower pacing. The authors' research shows that with the specialized instruction, STEPP students successfully met the same learning outcomes as their peers without learning disabilities. The authors believe that the lessons learned with these students are potentially helpful to all students. Students with undisclosed or undiagnosed learning disabilities in the classroom benefit from techniques gleaned from working with Cohorts 2011 and 2012. As the librarians continue to apply Universal Design for Learning principles to library instruction, more group activities are included, iPads are used to foster group activities, and video and other online tutorials are offered as a supplement to classroom instruction. The goal in using these techniques and those that will be added in the future is to close the gap between students with identified learning disabilities and their peer cohort.

\section{References}

1 http://www.popecenter.org/acrobat/vickers-mar2010.pdf

2 Burgstahler, Sheryl E. “Universal Design of Instruction: From Principles To Practice.” In Universal Design in Higher Education: From Principles to Practice, edited by Sheryl E. Burgstahler and Rebecca C. Cory, 29. Cambridge, MA: Harvard Education Press, 2008.

3 Black, Nancy E. "Blessing or Curse? Distance Delivery to Students with Invisible Disabilities.” Journal Of Library Administration 41, no. 1/2 (August 2004): 47-64. Library Literature \& Information Science Full Text (H.W. Wilson).

4 Mates, Barbara T., and Char Booth. "Information Power to All Patrons." Library Technology Reports 48, no. 7 (October 2012): 7-13. Library Literature \& Information Science Full Text (H.W. Wilson).

5 Mace, Ronald. 1985. “Universal Design: Barrier-Free Environments for Everyone.” Designers West 33 (1): $147-152$.

6 Silver, Patricia, Andrew Bourke, and K. C. Strehorn. 1998. "Universal Instructional Design in Higher Education: An Approach for Inclusion.” Equity \& Excellence in Education 31 (2): 47-51. doi:10.1080/1066568980310206. http:// www.tandfonline.com/doi/abs/10.1080/1066568980310206.

7 Zeff, Robbin. 2007. "Universal Design Across the Curriculum.” New Directions for Higher Education (137): $27-44$. http://search.ebscohost.com/login.aspx?direct=true\&db=a9h\&AN=24421396\&site=ehost-live.

8 Beacham, Nigel A. and James L. Alty. 2006. "An Investigation into the Effects that Digital Media can have on the Learning Outcomes of Individuals Who have Dyslexia.” Computers \& Education 47 (1): 74-93. doi:10.1016/j. compedu.2004.10.006.

9 Getzel, Elizabeth Evans, Shannon McManus, Lori W. Briel. 2004. "An effective model for college students with learning disabilities and attention deficit hyperactivity disorders.” Research to Practice Brief. Improving Secondary Education and Transition Services through Research. 3 (1). National Center on Secondary Education and Transition, Institute on Community Integration, University of Minnesota. 
10 Green, Ravonne A. 2009. "Empowering Library Patrons with Learning Disabilities.” Journal of Access Services 6 (1-2): 59-71. doi:10.1080/15367960802247817.

11 Weingand, Darlene E. 1990. "The invisible client: Meeting the needs of persons with learning disabilities." The Reference Librarian 14 (31): 77-88.

12 Black, Nancy E. 2004. "Blessing Or Curse? Distance Delivery to Students with Invisible Disabilities." Journal of Library Administration 41 (1): 47-64. http://search.ebscohost.com/login.aspx?direct=true\&db=llf\&AN=502920679 \&site=ehost-live.

13 O’Connor, L., T. Chodock, and E. Dolinger. 2009. Applying universal design to information literacy teaching students who learn differently at landmark college. Reference \& User Services Quarterly 49 (1): 24-32.

\section{Appendix: Pre - and Post- test Questions}

1. What is your Banner ID Number?

2. When I think about doing research at Joyner Library for my college classes, I feel: (Please write 2-3 sentences)

3. How confident do you feel finding books in the library on a particular research topic?
a. Very
b. Somewhat
c. Not Very
d. Not at All

4. How confident do you feel using library databases to find relevant articles on a topic?
a. Very
b. Somewhat
c. Not Very
d. Not at All

5. How comfortable do you feel asking for research assistance in a library?
a. Very
b. Somewhat
c. Not Very
d. Not at All

6. How familiar are you with avoiding plagiarism in your papers?
a. Very
b. Somewhat
c. Not Very
d. Not at All

7. If you are not familiar with a topic, where do you go to find more information? (Please write 2-3 sentences) When you're evaluating a website, which of the following criteria should you use? (Check all that apply)
a. Author's Credentials
b. Bias
c. Date of Publication/Creation
d. Discovered through a (popular/trusted) search engine such as Google, MSN, or Yahoo!
e. Layout/Design

8. A summary of a journal article is called:
a. Bibliography
b. Index
c. Abstract
d. Periodical
e. Atlas

9. Books in the library are shelved according to Library of Congress Classification. Library of Congress Classification arranges books primarily by:
a. Topic
b. Author Name
c. Title
d. Date of Publication

10. The following citation refers to what type of material?

Sheffield, P.E., \& Landrigan, P.J. (2011). Global Climate Change and Children's Health: Threats and Strategies for Prevention. Environmental Health Perspectives, 119(3), 291-298.
a. Journal Article
b. Book
c. Website
d. Book Article 